medRxiv preprint doi: https://doi.org/10.1101/2021.02.10.20249093; this version posted February $12,2021$. The copyright holder for this preprint (which was not certified by peer review) is the author/funder, who has granted medRxiv a license to display the preprint in

All rights reserved. No reuse allowed without permission.

\title{
The Milano Sforza Registers
}

Elia Biganzoli ${ }^{a *}$, Folco Vaglienti ${ }^{\mathrm{b} *}$, Patrizia Boracchi ${ }^{\mathrm{a}}$, Ester Luconi ${ }^{\mathrm{a}}$, Silvana Castaldi $^{\mathrm{c}, \mathrm{d}}$, Alfio Ferrara ${ }^{\mathrm{e}}$, Cristiana Panella ${ }^{\mathrm{f}}$ and Massimo Galli ${ }^{\mathrm{g}}$

*equally contributing authors

${ }^{a}$ Department of Clinical Sciences and Community Health \& DSRC, University of Milan, Italy;

${ }^{b}$ Department of Historical Studies, University of Milan, Italy; ${ }^{c}$ Department of Biomedical Sciences for Health, University of Milan, Italy; ${ }^{d}$ Fondazione IRCCS Ca'Granda OMP, Milan, Italy; "Department of Computer Science" Giovanni degli Antoni" \& DSRC, University of Milan, Italy; ${ }^{f}$ Royal Museum for Central Africa, Tervuren (Belgium); ${ }^{g}$ Department of Biomedical and Clinical Sciences "Luigi Sacco”, University of Milan, Italy.

\section{The Milano Sforza Registers}

\begin{abstract}
The Mortorum Libri of Milano (1452-1801) represent the first register in Europe based on the daily recording of the dead and detailed information about the social ties of decease people.
\end{abstract}

Mortorum Libri's protocol is the first example of a monitoring and prevention chain based on ethical and juridical individual responsibility.

The causes of death were codified according to the International Classification of Diseases (ICD-10) to relate the original classification with the present one.

This study has a particular reference to the Registers of the $15^{\text {th }}$ century and analyzes the mortality in 1480 as an example of the database application in epidemiology.

Keywords: Mortuorum Libri; public health; conservation science; epidemiology 
medRxiv preprint doi: https://doi.org/10.1101/2021.02.10.20249093; this version posted February 12, 2021. The copyright holder for this preprint (which was not certified by peer review) is the author/funder, who has granted medRxiv a license to display the preprint in All rights reserved. No reuse allowed without permission.

\section{Introduction}

By combining technological innovation and social history through a multidisciplinary and cross-cutting perspective (medicine, public health, history, statistics, social anthropology, information technology, and conservation science), this paper proposes a new approach to the acquisition and analysis of an exceptional source of epidemiological data in Europe scarcely utilized by scholars for a long time, the Mortuorum Libri (MML, MiSfoRe).

The MML (1452-1801) have been established by the Duke of Milan Francesco I Sforza. They constituted the first registration of the demographical data as well as of the causes of death in Italy (for example the first records of Venice obituaries date back to 1504 (Lazzari et al. 2020) and in Europe based on the daily recording of the dead and detailed information about the social ties of decease people (Alter and Carmichael 1999; Vaglienti 2013). Driven by the aim to earn the consent of the population, worried by recurrent plague epidemics (Cohn and Alfani 2007), Francesco Sforza conceived the Registers of the Death as a tool to check the rate of mortality and morbidity among the population, and to detect suspicious cases of plague or violent death (Vaglienti and Cattaneo 2010).

The revolutionary vision of Sforza was confirmed, in 1456, by the foundation of the first great European hospital, the Ospedale Maggiore, called by the Milanese people $\mathrm{Ca}^{\prime}$ Granda (Great House), conceived as a place of care and not only as a hospice for the incurables. With this perspective, Sforza claims to the state functions of assistance and care hitherto completely delegated to religious institutions. Designed for the early detection of epidemics the MML have been among the earliest examples of public health intervention in pre-industrial Europe.

The aim of Sforza was clearly to warrant a rapid containment of the spread of contagious diseases with rapid measures such as the closure of the affected homes or the transfer of sick people to the Lazzaretto (Lazaret). This approach consisted in a capillary system of control of 
medRxiv preprint doi: https://doi.org/10.1101/2021.02.10.20249093; this version posted February $12,2021$. The copyright holder for this preprint (which was not certified by peer review) is the author/funder, who has granted medRxiv a license to display the preprint in

All rights reserved. No reuse allowed without permission.

causes of death and, in particular circumstances, of sick people, without distinction of sex, class, or age, also including residents of passage and foreigners.

About this outstanding historical and anthropological source, this paper aims to describe the methodology adopted for filling the MML, with particular reference to the Registers of the 15 th century, and to analyze the mortality and the causes of death in 1480 , a year without plague. ${ }^{1}$

The uniqueness of this corpus lies in the accuracy in collecting personal data and information on the social ties of the patient, which mirrors not only the perspective of social inclusion of the Sforza healthcare system through the individual bodily engagement of the links of the chain but also the importance of information on the proximity social network (household, neighborhood) to follow the evolution of contagion. Such an accurate method of survey remained utmost meticulous and effective for more than one century, in particular to face virulent plague epidemics which stroked the country in 1476-78 and in $1483-85 .^{2}{ }^{2}$ The reports of 1485 give a taste of the elements which were taken into consideration by the officers. In several cases, they report not only symptoms and causes of sickness and death but also the timing laps from the beginning of symptoms and the visit of the health officer, and the symptomatic context of the household. Consequently, public officials were in charge of inspecting the corpses personally, collecting the deceased's data and registering them in the

\footnotetext{
${ }^{1}$ The research project MiSfoRe was carried out by the Department of Historical Studies of the University of Milan, in collaboration with the direction of Archivio di Stato di Milano, the chair of Medical Statistics of the Department of Clinical Sciences and Community Health, the chair of Information Sciences of the Department of Computer Science "Giovanni degli Antoni" \& DSRC, and the chair of Infectious Diseases of the Department of Biomedical and Clinical Science L. Sacco of the same University. The last three departments are joined to the Data Science Research Centre of the University of Milan.

${ }^{2}$ The pandemic 1476-1478 also determined the publication of several tractatus on plague in Italy. Between 1480 and 1499, 35 studies on plague have been published, among which, in 1478, De peste by surgeon and philosopher Jacopo Soldi, the Trattato de la pestilentia by Girolamo Manfredi (1479), the Consilium contra pestilentia by Gentile da Foligno (1479), and De Pestilentia by Giovanni Calori. In 1481 Marsilio Ficino published the Consilio contro la pestilentia, which was republished several times between 1575 and 1580 when strong plague epidemics resurfaced (Katinis 2007; Duranti 2008).
} 
medRxiv preprint doi: https://doi.org/10.1101/2021.02.10.20249093; this version posted February 12, 2021. The copyright holder for this preprint (which was not certified by peer review) is the author/funder, who has granted medRxiv a license to display the preprint in All rights reserved. No reuse allowed without permission.

same day or within a day after death. The same duty was imposed to the graduate doctors whenever their patients have died at home.

Although they cover four hundred and fifty years and that they are extraordinarily rich in data as being much more complete than the later Italian and foreign registers, unlike London's Bills of Mortality, MML have always remained manuscripts and their use has remained limited to health offices. The several governments that succeeded each other in ruling the city since the beginning of the $15^{\text {th }}$ century have never given them publicity, keeping in fact scholars aside from this data. MML have been scarcely exploited and unexplored by the modern epidemiology until the 19th century (Ferrario 1840) and remained in further long oblivion until the seventies of the last century (Cipolla 1974; Albini 1982; Zanetti 1976). Such oblivion is also due to the strong international visibility of the Bills of Mortality of London, established in 1592 and maintained until the 19th century. The Bills are the most renown source of morbidity and mortality data on which public health sciences have been implemented since early origins (Heitman 2020). The most renown, but neither the first established nor the most exhaustive.

There are two important differences between parish Registers as the London Bills and the Milan Sforza Registers: in the Books of the Dead of the city of Milan the causes of death are reported for all individuals, and have been determined by a doctor or a public official (and not by a responsible for the parish (Rollo-Koster 2016)); moreover, they report the dates of death and not those of burial.

\section{Materials and methods}

\section{The corpus of Mortuorum Libri}

The State Archives of Milan presently holds a continuous series of 287 handwritten Registers (an example of two pages of the Registers is shown in Figure 1), with only some discontinuities in the $15^{\text {th }}$ and early $16^{\text {th }}$ century due to the fire of the headquarters of the Office of Health (Ufficio di Sanità), where the volumes were stored, on the night between December 31, 1501 
medRxiv preprint doi: https://doi.org/10.1101/2021.02.10.20249093; this version posted February 12, 2021. The copyright holder for this preprint (which was not certified by peer review) is the author/funder, who has granted medRxiv a license to display the preprint in All rights reserved. No reuse allowed without permission.

and January 1, 1502. The Register of 1480 starts from January 23rd. It was not possible to trace the recordings of the first 22 days, which should have been accessible to Ferrario (Ferrario 1840), who reported in January 1480 a total of 170 deaths, and a total of 1938 deaths in the entire year.

The Registers of the 15th century, which were written in Latin, systematically reported:

(1) In which of the six parts of the city, named according to the six main doors of the city wall, the death occurred (the city doors were called, going clockwise starting from the North, "Porta Nuova, Porta Orientale, Porta Romana, Porta Ticinese, Porta Vercellina, Porta Comasina”) (Tucci, Ronza, and Giordano 2011).

(2) The Parish where the deceased individual has lived or where the death occurred or sometimes the burial place.

(3) The place where the death occurred: hospital, prison, on the street, or in some other special locations.

(4) The name, surname, or nickname of the deceased person. For children, adolescents and, unmarried women were reported (with few exceptions) the name of their father (living or deceased) or, if the father was unknown, of their mother. For abandoned illegitimate children it was always reported a last name (typically: "da Milano" or "Colombo", according to an established custom), or the denomination: "son, or daughter, of the hospital". The name of married women is often accompanied by the name and the surname of their husband.

(5) The social and professional status of the deceased (of the father in the case of children or the husband in the case of adult women). Nobility or ecclesiastical titles and those arising from the position in the public administration, ducal court or ducal army, and the position held in hospitals and charitable institutions 
medRxiv preprint doi: https://doi.org/10.1101/2021.02.10.20249093; this version posted February 12, 2021. The copyright holder for this preprint (which was not certified by peer review) is the author/funder, who has granted medRxiv a license to display the preprint in

All rights reserved. No reuse allowed without permission.

were also included. The data reported also if the dead person has belonged to a liberal profession, as well as the status of domestic worker, the condition of poverty, or the status of prison inmate.

(6) The age at death, expressed in years for adults, and in months, days, or even hours for infants.

(7) With a few missing cases the gender can be extrapolated from the person's name.

(8) The cause of death, whose registration was initially aimed mainly to distinguish between plague and current causes of death, using rather coarse definitions. In a short time, the registering evaluated into an accurate report for all the causes, including the description of symptoms, as in this sample coming from the register of 1459: "Long-suffering of quartan fever, the night before he had a paroxysm, aggravated by an indigestion that caused heart palpitations and blurred intellect, then evolved into syncope and apoplexy that led to the death ". A code specified, in case of plague, if it was a new case or an already known one.

(9) The name of the official in charge of inspecting the bodies and determine the causes of to be transcribed on the register along with all other information requested. This official could be a 'collegiate' doctor (indicated in this case with personal name and title) or a health official appointed to this specific duty; less frequently, the Elder of the parish or, in exceptional cases, the gravedigger. 


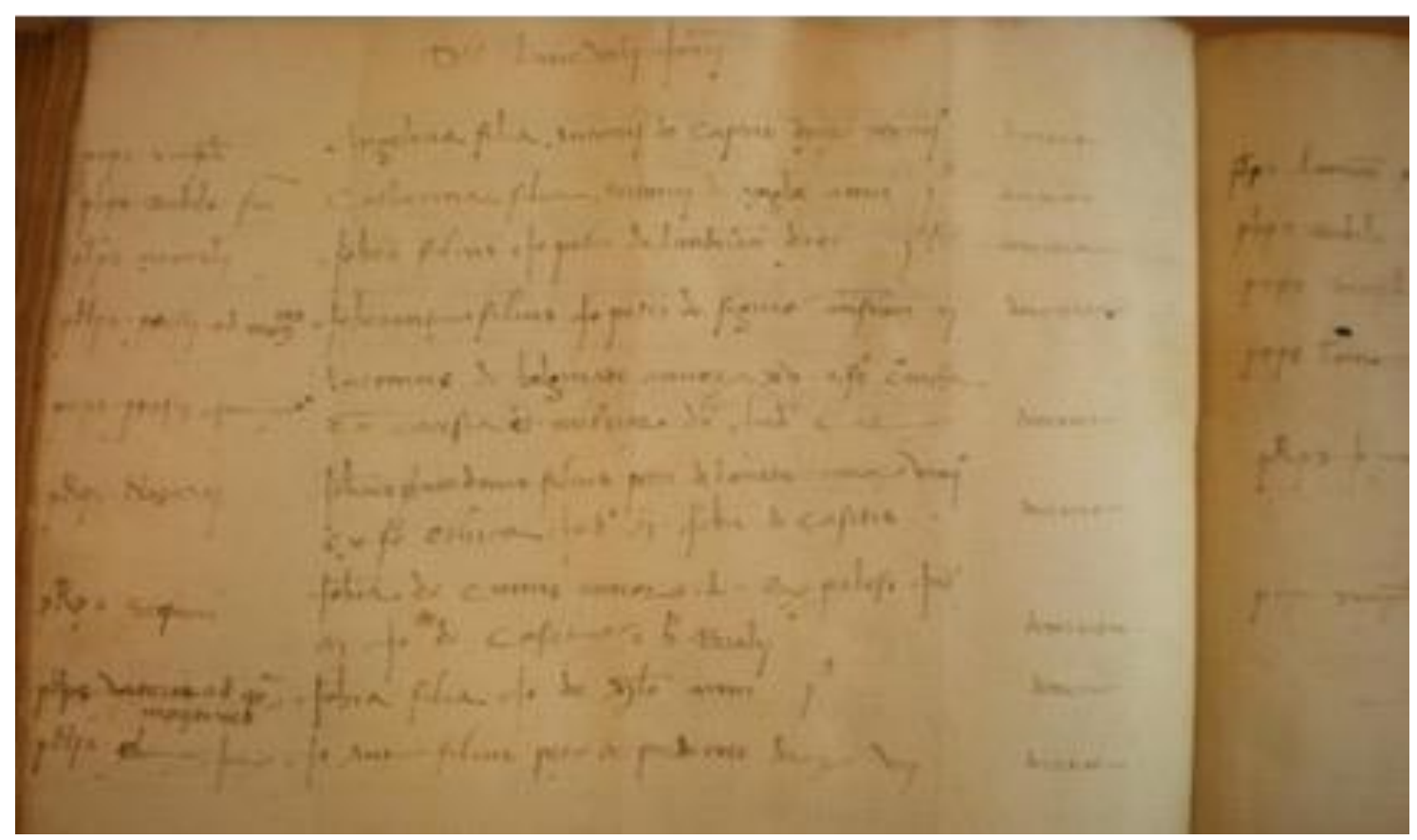

Figure 1. Sample picture of Mortorum Libri (kindly authorized by State Archives of Milan)

\section{Research methods}

The causes of death and the demographic data of deceased persons enlisted in the Registers have been collected and translated from Latin by an expert paleographer and were later transferred to a database. A conceptual overview of the data available in the MML is shown in Figure 2, where data are described in terms of entities, attributes, relations among entities, and their cardinality constraints. The main entity is the DECEASE, which represents the event of a death as recorded in the MML corpus. Such an event is associated with a date and has a PROVENANCE, that is the reference to the specific book in the corpus where the decease record has been retrieved. A variety of other entities, each depicting the historical and interpretative background of the death event, has been conceptualized in terms of three main contexts, namely Social Context, that is related to the people directly or indirectly involved in the death event and their mutual relations; a Geographic Context, related to the distribution of the events over the territory of the historical city of Milan, and a Clinical Context, related to the hypothesis and the causes concerning the death. In particular, two main kinds of causes, 
medRxiv preprint doi: https://doi.org/10.1101/2021.02.10.20249093; this version posted February $12,2021$. The copyright holder for this preprint (which was not certified by peer review) is the author/funder, who has granted medRxiv a license to display the preprint in All rights reserved. No reuse allowed without permission.

namely EVENTS (e.g., incidents, fights, murder) and DISEASE (i.e., any natural cause of death that is interesting from a clinical perspective) have been also considered.

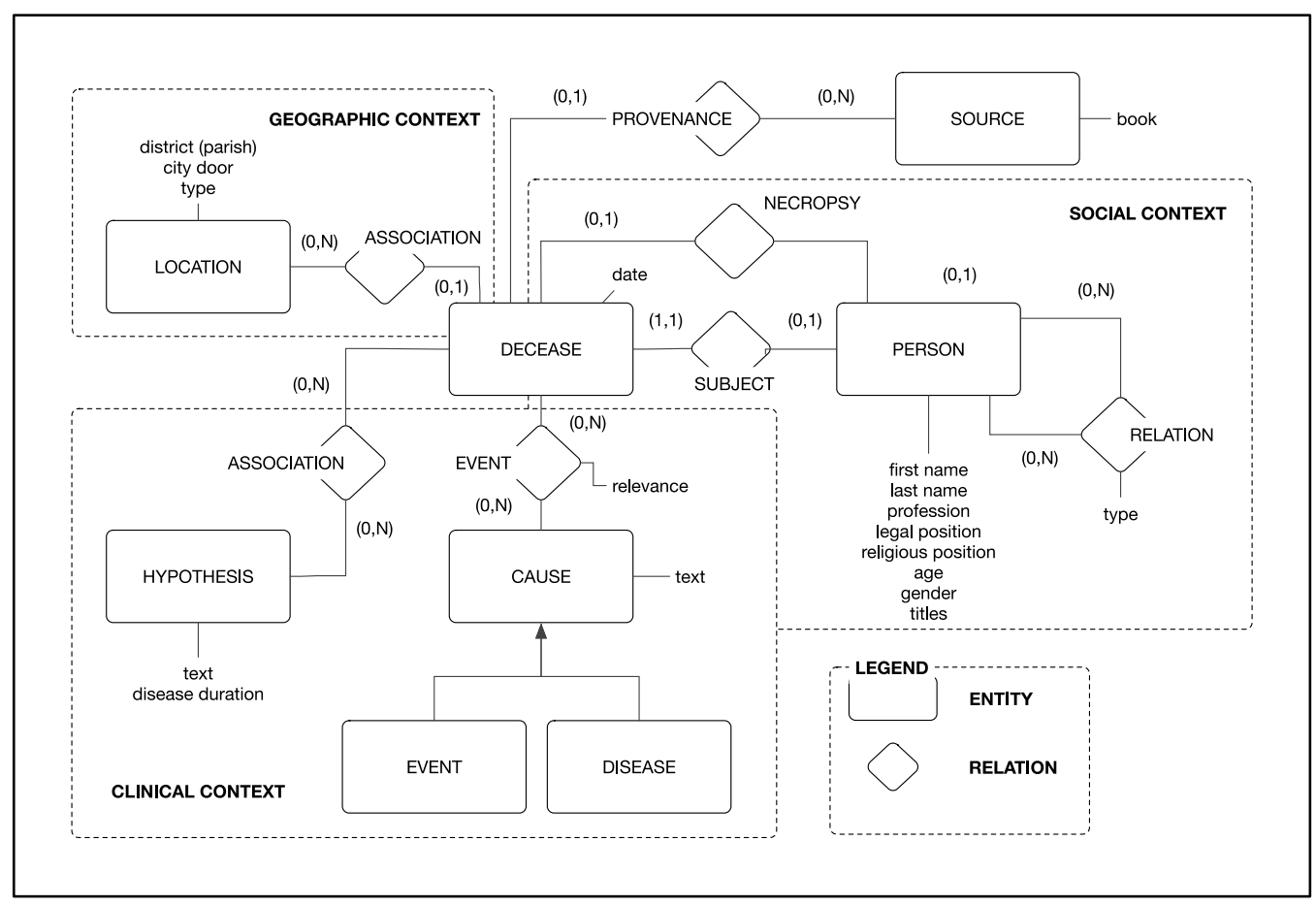

Figure 2. A conceptual overview of the data available in the Mortuorum Libri of Milan

To obtain an integrity of data collected (there is the need to uniform data collected to perform analysis such as statistical analysis and spatial analysis, and there is the need to obtain data correctly readable by a software such as R (R Core Team 2020)) the following steps were performed:

(1) The potential presence for repeated records was checked and they were removed from the dataset.

(2) The presence of special characters (for example $\tilde{\mathrm{A}}$ ) in the header and in the cell were modified. A check was carried out to whether the missing data had been identified in the same way. If not, a recording of them has been carried to obtain a unique identification. If the information about the missing data could be deduced from other fields, a correction has been made (i.e.: a subject had a NA 
medRxiv preprint doi: https://doi.org/10.1101/2021.02.10.20249093; this version posted February 12, 2021. The copyright holder for this preprint (which was not certified by peer review) is the author/funder, who has granted medRxiv a license to display the preprint in All rights reserved. No reuse allowed without permission.

for Sex, but the name of this subject was Giovannina, so the Sex could be codified as female).

(3) A spelling or typing error correction has been performed (i.e.: A. Maria al Circolo has been corrected as S. Maria al Circolo). In those cases where the inconsistencies or errors could not be corrected based on the content of the dataset, the expert was asked to check. The reported causes of death have been tentatively interpreted according to contemporary medical treatises, in particular as regards the classification of fevers (Sennert 1608; Borsieri de Kanilfeld 1781).

The causes of death were finally codified according to the International Classification of Diseases (made by the World Health Organization) to obtain a link between the original classification and the current classification criteria (ICD-10).

The ICD is a classification system in which disease and injuries are placed into groups based on defined criteria. Thanks to this instrument, information about morbidity and mortality can be encoded to get comparable data for statistical and epidemiological monitoring. The first classification list, in 1893, only concerned the causes of death. From 1948 it also included the morbidity codes. The ICD-9-CM is the version of the $9^{\text {th }}$ revision of ICD classification that was modified and extended with the clinical coding information (intervention, diagnostic and therapeutic procedures). In 1994 the WHO has completed the publication of the three volumes of ICD-10. At the moment this classification is adopted in Italy to code causes of death in the ISTAT survey on deaths, and to code the hospital records. ICD-11 comes into effect in 2022 and it gathers the different modifications and adaptations executed over time adding clinical needs.

The codification of the causes of death in Milan Sforza Registers according to ICD-10 (WHO, 2016) has implied the steps below: 
medRxiv preprint doi: https://doi.org/10.1101/2021.02.10.20249093; this version posted February 12, 2021. The copyright holder for this

preprint (which was not certified by peer review) is the author/funder, who has granted medRxiv a license to display the preprint in perpetuity.

All rights reserved. No reuse allowed without permission.

(1) Identification of the most frequent medical terms in the string of causes of death in the original database (i.e.: febbre, pleurite, catarro).

(2) Those terms have been identified as keywords and an appropriate code of ICD10 has been attributed to each of them in relation to the description of the first level of classification (see Table 1). I.e.: febbre was codified as XVIII, pleurite was codified as X, catarro was codified as X).

(3) Three additional fields have been compiled for each record containing the classification of the cause of death extracted from the string, according to the predefined keywords.

(4) The final classification of the cause of death has been defined according to the more indicative cause of death in the three fields. 
medRxiv preprint doi: https://doi.org/10.1101/2021.02.10.20249093; this version posted February $12,2021$. The copyright holder for this preprint (which was not certified by peer review) is the author/funder, who has granted medRxiv a license to display the preprint in

All rights reserved. No reuse allowed without permission.

Table 1. ICD10-Fist level classification

\begin{tabular}{|l|l|}
\hline I & Certain infectious and parasitic diseases \\
\hline II & Neoplasms \\
\hline III & $\begin{array}{l}\text { Diseases of the blood and blood-forming organs } \\
\text { and certain disorders involving the immune mechanism }\end{array}$ \\
\hline IV & Endocrine, nutritional and metabolic diseases \\
\hline V & Mental and behavioural disorders \\
\hline VI & Diseases of the nervous system \\
\hline VII & Diseases of the eye and adnexa \\
\hline VIII & Diseases of the ear and mastoid process \\
\hline IX & Diseases of the circulatory system \\
\hline X & Diseases of the respiratory system \\
\hline XI & Diseases of the digestive system \\
\hline XII & Diseases of the skin and subcutaneous tissue \\
\hline XIII & Diseases of the musculoskeletal system and connective tissue \\
\hline XIV & Diseases of the genitourinary system \\
\hline XV & Pregnancy, childbirth and the puerperium \\
\hline XVI & Certain conditions originating in the perinatal period \\
\hline XVII & Congenital malformations, deformations and chromosomal abnormalities \\
\hline XVIII & $\begin{array}{l}\text { Symptoms, signs and abnormal clinical and laboratory findings, not elsewhere } \\
\text { classified }\end{array}$ \\
\hline XIX & Injury, poisoning and certain other consequences of external causes \\
\hline XX & External causes of morbidity and mortality \\
\hline XXI & Factors influencing health status and contact with health services \\
\hline & \\
\hline
\end{tabular}

\section{Results}

The original information reported in the MML were added to the recoded cause of death according to ICD10 and a first version of the database was then obtained. The content of the database was detailed in Table 2 . 
medRxiv preprint doi: https://doi.org/10.1101/2021.02.10.20249093; this version posted February $12,2021$. The copyright holder for this preprint (which was not certified by peer review) is the author/funder, who has granted medRxiv a license to display the preprint in perpetuity.

All rights reserved. No reuse allowed without permission.

Table 2. Variables in the database and their codification

\begin{tabular}{|c|c|c|c|}
\hline Variables & Codification & $\begin{array}{l}\text { Definition (if not } \\
\text { defined before) }\end{array}$ & Levels (if categorical) \\
\hline n. & Numeric integer & $\begin{array}{l}\text { Progressive number used } \\
\text { by identification of } \\
\text { subjects }\end{array}$ & \\
\hline Register & Character & $\begin{array}{l}\text { The identification of the } \\
\text { register of the records }\end{array}$ & $76 / I$ \\
\hline Door & Character & & $\begin{array}{l}\text { Comasina, Nuova, } \\
\text { Orientale, } \\
\text { Romana, } \\
\text { Ticinese, } \\
\text { Vercellina }\end{array}$ \\
\hline Parish & Character & & \\
\hline Death Date & $\begin{array}{l}\text { Date (yyyy-mm- } \\
\text { dd) }\end{array}$ & The date of death & \\
\hline Subject & Character & $\begin{array}{l}\text { The name, surname or } \\
\text { nickname of the deceased } \\
\text { person }\end{array}$ & \\
\hline Name & Character & $\begin{array}{l}\text { The name of the subject } \\
\text { (extrapolated from the } \\
\text { variable "Subject") }\end{array}$ & \\
\hline Surname & Character & $\begin{array}{l}\text { The surname of the } \\
\text { subject (extrapolated } \\
\text { from the variable } \\
\text { "Subject") }\end{array}$ & \\
\hline Age & Character & & \\
\hline Sex & Character & & $\mathrm{F}, \mathrm{M}$ \\
\hline Profession of the subject & Character & & $\begin{array}{l}\text { i.e.: canevario, } \\
\text { giurisperito }\end{array}$ \\
\hline Profession of the relative & Character & & \\
\hline Legal status & & & $\begin{array}{l}\text { i.e.: religious, } \\
\text { widowed, servant }\end{array}$ \\
\hline Type of religious & Character & For legal status=religious & $\begin{array}{l}\text { i.e.: canon, } \\
\text { monk, nun, } \\
\text { presbyter }\end{array}$ \\
\hline $\begin{array}{l}\text { Honorary titles of the } \\
\text { subject }\end{array}$ & Character & & $\begin{array}{l}\text { i.e.: domina, dominus, } \\
\text { maestro }\end{array}$ \\
\hline $\begin{array}{l}\text { Honorary titles of the } \\
\text { relatives }\end{array}$ & Character & & i.e: maestro \\
\hline Name of the relative & Character & & $\begin{array}{l}\text { i.e.: Lorenzo, } \\
\text { Ambrogio, } \\
\text { Gabriele }\end{array}$ \\
\hline Degree of kinship & Character & & i.e.: father, husband \\
\hline Relative state & Character & & i.e.: dead \\
\hline Type of the place of death & Character & & $\begin{array}{l}\text { i.e.: hospital, } \\
\text { castle, } \\
\text { monastery }\end{array}$ \\
\hline Name of the place of death & Character & & $\begin{array}{l}\text { i.e.: Monastero Nuovo, } \\
\text { ospedale di } \\
\text { S.Caterina, }\end{array}$ \\
\hline
\end{tabular}


medRxiv preprint doi: https://doi.org/10.1101/2021.02.10.20249093; this version posted February $12,2021$. The copyright holder for this preprint (which was not certified by peer review) is the author/funder, who has granted medRxiv a license to display the preprint in perpetuity.

All rights reserved. No reuse allowed without permission.

\begin{tabular}{|c|c|c|c|}
\hline & & & $\begin{array}{l}\text { monastero di } \\
\text { S.Francesco }\end{array}$ \\
\hline Age_years & Numeric integer & $\begin{array}{l}\text { Age of the subjects } \\
\text { expressed in years } \\
\text { (extrapolated from Age) }\end{array}$ & \\
\hline Age_months & Numeric integer & $\begin{array}{l}\text { Age of the subjects } \\
\text { expressed in months for } \\
\text { children and infant, were } \\
\text { appropriated } \\
\text { (extrapolated from Age) }\end{array}$ & \\
\hline Age_days & Numeric integer & $\begin{array}{l}\text { Age of the subjects } \\
\text { expressed in days for } \\
\text { children and infant, were } \\
\text { appropriated (extrapolated } \\
\text { from Age) }\end{array}$ & \\
\hline Tot_age_days & Numeric integer & $\begin{array}{l}\text { Calculating from } \\
\text { Age_months, Age_years, } \\
\text { Age_days }\end{array}$ & \\
\hline Cause of death & Character & & \\
\hline $\begin{array}{l}\text { Physician name } \\
\text { (Necroscopi) }\end{array}$ & Character & & $\begin{array}{l}\text { i.e.: Catelano } \\
\text { (Iuditio } \\
\text { Catelani), } \\
\text { Maestro } \\
\text { Ambrogio } \\
\text { Pasquali, Maestro } \\
\text { Matteo da Busto }\end{array}$ \\
\hline tip 1 (ICD10-keyword) & Character & $\begin{array}{l}\text { Extrapolated from the } \\
\text { Cause of death. The } \\
\text { keywords useful for the } \\
\text { identification of the } \\
\text { appropriate ICD10 }\end{array}$ & \\
\hline $\begin{array}{l}\text { description suggestion } 1 \\
\text { (ICD10-description) }\end{array}$ & Character & $\begin{array}{l}\text { Description of } \\
\text { tip } 1 \text { (ICD-10-keyword) }\end{array}$ & \\
\hline Cause of death-1 & Character & $\begin{array}{l}\text { A code (roman number) } \\
\text { for the identification of } \\
\text { the first cause of death } \\
\text { (extrapolated from tip } 1 \\
\text { (ICD10-keyword)) }\end{array}$ & \\
\hline Cause of death-2 & Character & $\begin{array}{l}\text { A code (roman number) } \\
\text { for the identification of } \\
\text { the first cause of death } \\
\text { (extrapolated from tip } 1 \\
\text { (ICD10-keyword)) }\end{array}$ & \\
\hline Cause of death-3 & Character & $\begin{array}{l}\text { A code (roman number) } \\
\text { for the identification of } \\
\text { the first cause of death } \\
\text { (extrapolated from tip } 1 \\
\text { (ICD10-keyword)) }\end{array}$ & \\
\hline Cause of death-1 num & Numerical integer & $\begin{array}{l}\text { Numerical value. The } \\
\text { Cause of death- 1expressed } \\
\text { as number }\end{array}$ & \\
\hline
\end{tabular}


medRxiv preprint doi: https://doi.org/10.1101/2021.02.10.20249093; this version posted February 12,2021 . The copyright holder for this preprint (which was not certified by peer review) is the author/funder, who has granted medRxiv a license to display the preprint in

All rights reserved. No reuse allowed without permission.

\begin{tabular}{|l|l|l|l|}
\hline Cause of death-2 num & Numerical integer & $\begin{array}{l}\text { Numerical value. The } \\
\text { Cause of death-2 } \\
\text { expressed as number }\end{array}$ & \\
\hline Cause of death-3 num & Numerical integer & $\begin{array}{l}\text { Numerical value. The } \\
\text { Cause of death-3 } \\
\text { expressed as number }\end{array}$ & DEAD/ALIVE \\
\hline Outcome in case of plague & Character & & $\begin{array}{l}\text { 0= nonviolent } \\
\text { death 1=violent } \\
\text { death (suicide, } \\
\text { homicide or injuries) }\end{array}$ \\
\hline Violent death & Indicator variable & & \\
\hline
\end{tabular}

This version of the database allows the investigation of the mortality patterns both in plague periods and in periods free of plague. These latter will give the opportunity to describe the causes of death that were common in relation to the socio-economical and demographical structures in different periods. As an example of the use of the database for analyzes of mortality, in a period free of plague we show some descriptive statistics about data of 1480 .

Table 3 shows the causes of natural death (ICD-10) for all subjects (subjects without age are excluded from the analysis) with the cause, the number of subjects, and the percentage. $\mathrm{N}=1788$.

Table 4 presents the distribution of age (years) at death for all subjects (excluding the subjects with an unknown age). 
medRxiv preprint doi: https://doi.org/10.1101/2021.02.10.20249093; this version posted February $12,2021$. The copyright holder for this preprint (which was not certified by peer review) is the author/funder, who has granted medRxiv a license to display the preprint in

All rights reserved. No reuse allowed without permission.

Table 3. The distribution of the causes of mortality, as classified according to ICD-10

\begin{tabular}{|l|l|}
\hline Causes of death (ICD-10) & Number of subject (\%) \\
\hline Perinatal mortality nd & $347(19.52 \%)$ \\
\hline Children without a diagnosis & $293(16.48 \%)$ \\
\hline Protracted fever states & $204(11.47 \%)$ \\
\hline Acute pneumonia & $119(6.69 \%)$ \\
\hline Hetical fever & $111(6.24 \%)$ \\
\hline Fever with respiratory symptoms & $82(4.61 \%)$ \\
\hline Fever with GI symptoms & $68(3.82 \%)$ \\
\hline Dropsy & $60(3.37 \%)$ \\
\hline Infections of various types & $48(2.7 \%)$ \\
\hline Consumption & $44(2.47 \%)$ \\
\hline Worms & $40(2.25 \%)$ \\
\hline Different non-infectious causes & $36(2.02 \%)$ \\
\hline Cerebrovascular & $35(1.97 \%)$ \\
\hline Asthma, heart problem & $32(1.8 \%)$ \\
\hline Fever with exanthema & $32(1.8 \%)$ \\
\hline Possible UTI/ urinary calculus & $32(1.8 \%)$ \\
\hline Childbirth or related causes & $30(1.69 \%)$ \\
\hline Diarrhea, dysentery without fever & $28(1.57 \%)$ \\
\hline Chronic respiratory disease & $27(1.52 \%)$ \\
\hline Unknown/ undetermined/ unreadable & $22(1.24 \%)$ \\
\hline Old age & $21(1.18 \%)$ \\
\hline Jaundice/ hepatic pathology & $18(1.01 \%)$ \\
\hline Cancer & $14(0.79 \%)$ \\
\hline Childhood seizures (< age of 7 years) & $7(0.39 \%)$ \\
\hline Heart disease & $7(0.39 \%)$ \\
\hline Hunger & $7(0.39 \%)$ \\
\hline Seizures (epilepsy) (>age of 8 years) & $3(0.34 \%)$ \\
\hline Erysipelas & \\
\hline Hemorrhagic manifestations & $(0.11 \%)$ \\
\hline Smallpox & $2 \%)$ \\
\hline Gangrene & \\
\hline
\end{tabular}


medRxiv preprint doi: https://doi.org/10.1101/2021.02.10.20249093; this version posted February 12, 2021. The copyright holder for this preprint (which was not certified by peer review) is the author/funder, who has granted medRxiv a license to display the preprint in All rights reserved. No reuse allowed without permission.

Table 4. Summary statistics for the distribution of age (years), for all subjects and subdivided according to sex.

\begin{tabular}{|c|c|c|c|c|c|c|c|c|}
\hline & Mean & Median & Min & Max & $\begin{array}{c}\text { First } \\
\text { quartile }\end{array}$ & $\begin{array}{c}\text { Third } \\
\text { Quartile }\end{array}$ & $\begin{array}{c}\text { Standard } \\
\text { deviation }\end{array}$ & $\begin{array}{c}\text { Number } \\
\text { of } \\
\text { subjects }\end{array}$ \\
\hline $\begin{array}{c}\text { All } \\
\text { subjects }\end{array}$ & 26.17 & 17.00 & 0.00 & 100.00 & 1.00 & 50.00 & 27.57 & 1811 \\
\hline Female & 26.78 & 18.00 & 0.00 & 100.00 & 1.00 & 50.00 & 27.58 & 910 \\
\hline Male & 25.55 & 14.00 & 0.00 & 100.00 & 0.00 & 50.00 & 27.56 & 901 \\
\hline
\end{tabular}

\section{Discussion}

The MiSfoRe project proposes an interdisciplinary approach to the MML including Health Sciences, Human Sciences, and ICTs to provide epidemiological data within a historical and anthropological perspective. A further aim of the project is to apply this multi-level approach to other national sources of data on mortality and to create a network on information that could improve the knowledge of the interaction between social and biological mechanisms. Moreover, the project aims to stress the huge potential of the astonishing MML method, which seems to respond to an "ante litteram" ethnographic data collecting to face the urgency of epidemics. The meticulousness of the description of symptoms and of the information on the social context of the patients does reveal the strong relationship between individuals and community conceived by Sforza, in the wake of the neo-platonic philosophy, which considered the individual body as a microcosm reflecting the universe. First of all, the Registers reveal a policy of care based on individual responsibility, and that beyond social status, sex, and nationality, and such a virtuous chain of responsibility allows to be timing. It would be impossible, also considering the experience of COVID-19 in Italy, in particular in Lombardy, to not envisage Sforza's method as an example for the contemporary health protocols and policies based on proximity and on a network of social ties of empathy and engagement which seem to level the social stratification of the community based on an ethical mission. 
medRxiv preprint doi: https://doi.org/10.1101/2021.02.10.20249093; this version posted February 12, 2021. The copyright holder for this preprint (which was not certified by peer review) is the author/funder, who has granted medRxiv a license to display the preprint in

All rights reserved. No reuse allowed without permission.

\section{Acknowledgements}

The Authors are grateful to Dr.Benedetto Luigi Compagnoni, Director of Archivio di Stato di Milano for letting access the Mortuorum Libri.

Declaration of interest statement

No potential competing interest was reported by the authors

\section{References}

Albini, G. 1982. Guerra, Fame, Peste: Crisi Di Mortalità e Sistema Sanitario Nella Lombardia Tardomedioevale. Cappelli.

Alter, G.C. and Carmichael, AG. 1999. "Classifying the Dead: Toward a History of the Registration of Causes of Death." Journal of the History of Medicine and Allied Sciences 54(2): 114-32. https://doi.org/10.1093/jhmas/54.2.114.

Borsieri de Kanilfeld, G. 1781. 1 Institutionum Medicinae Practicae. 'Typ. Imp. Mon. S. Ambrosii Majoris.

Cipolla, C. M. 1974. "I Libri Dei Morti." In Le Fonti Della Demografia Storica in Italia: Atti Del Seminario Di Demografia Storica, 1971-1972, Vol. 1, Part 2, Rome: Comitato italiano per lo studio della demografia storica, 851-866.

Cohn, Jr., Samuel K, and Alfani G. 2007. "Households and Plague in Early Modern Italy." The Journal of Interdisciplinary History 38(2): 177-205. http://www.jstor.org/stable/20143583.

Ferrario, G. 1840. 2 Statistica Medica Di Milano Dal Secolo 15. Fino Ai Nostri Giorni. Guglielmini \& Redaelli.

Heitman, K. 2020. "Authority, Autonomy and the First London Bills of Mortality." Centaurus 62(2): $275-84$.

Katinis, T. 2007. Medicina e filosofia in Marsilio Ficino: il 'Consilio contro la pestilentia'. Roma: Edizioni di Storia e Letteratura. 
medRxiv preprint doi: https://doi.org/10.1101/2021.02.10.20249093; this version posted February 12, 2021. The copyright holder for this preprint (which was not certified by peer review) is the author/funder, who has granted medRxiv a license to display the preprint in All rights reserved. No reuse allowed without permission.

Lazzari G, Colavizza G, Bortoluzzi F, Drago D, Erboso A, Zugno F, Kaplan F, Salathé M 2020.

"Death in Venice: A Digital Reconstruction of a Large Plague Outbreak During 16301631." medRxiv DOI: 10.1101/2020.03.11.20034116.

Manfredi, G. 2008. Tractatus de pestilentia (curated by T. Duranti). Bologna: Clueb.

R Core Team (2020). R: A language and environment for statistical computing. R Foundation for Statistical Computing, Vienna, Austria. URL https://www.R-project.org/

Rollo-Koster, J. 2016. Death in Medieval Europe: Death Scripted and Death Choreographed. Taylor \& Francis.

Sennert D. 1608. De Febribus Libri IV. 3rd ed. ed. Frankfurt and Wittenberg.

Tucci, M., Ronza RW, and Giordano A. 2011. "Fragments from Many Pasts: Layering the Toponymic Tapestry of Milan.” Journal of Historical Geography 37(3): 370-84.

Vaglienti, F. 2013. "Noluit Ire Ad Visum: I Segreti Dei Mortuorum Libri Di Milano Da Francesco Sforza a Leonardo Da Vinci:(1452-1485).” In La Popolazione Di Milano Dal Rinascimento: Fonti Documentarie e Fonti Materiali per Un Nuovo Umanesimo Scientifico, Edizioni Biblioteca Francescana, 25-59.

Vaglienti, F. and Cattaneo C. 2010. "A Medieval Contribution to the History of Legal Medicine: The First European Necroscopic Registry." International Journal of Legal Medicine 124(6): 669-70. https://doi.org/10.1007/s00414-009-0378-z.

WHO. 2016 "ICD-10: international statistical classification of diseases and related health problems - 10th revision, Fifth edition.", https://apps.who.int/iris/bitstream/handle/10665/246208/9788894307610-V1ita.pdf? sequence $=108 \&$ is Allowed $=y$

Zanetti, D.E. 1976. "La Morte a Milano Nei Secoli XVI-XVIII.” Rivista storica italiana 4: $803-51$. 